Review Article

\title{
Introduction to the Integrated Nutrient Management Strategies and Their Contribution to Yield and Soil Properties
}

\author{
Mostafa Mohamed Selim (iD) \\ Field Crops Research Department, Agricultural Division, National Research Centre, 33 Bohouth St., Dokki, Giza 12622, Egypt \\ Correspondence should be addressed to Mostafa Mohamed Selim; selim_family@hotmail.com
}

Received 3 October 2019; Accepted 24 December 2019; Published 13 May 2020

Academic Editor: Silvia Imhoff

Copyright (C) 2020 Mostafa Mohamed Selim. This is an open access article distributed under the Creative Commons Attribution License, which permits unrestricted use, distribution, and reproduction in any medium, provided the original work is properly cited.

\begin{abstract}
Alleviation of poverty and achievement of zero-hunger target and food security are significant challenges faced by agricultural planners worldwide. Improving many agronomic approaches, which have drastic effects on crop growth and yield, is urgently needed to report this aim. Replacement of a part of chemical fertilizers by organic manure through a simple technique of using minimum effective dose of sufficient and balanced quantities of organic and inorganic fertilizers in combination with specific microorganisms, called INM, has a bright solution in this area. Recently, several investigators reported that integrated use of chemical fertilizers with organic manure is becoming a quite promising practice not only for maintaining higher productivity but also for greater stability to crop production. In addition, INM acts as a source of energy, organic carbon, and available nitrogen for the growth of soil microbes and improvement of physical properties of soil, and also have great residual effect on subsequent crops. So, the key component of the INM goal is to reach the eco-friendly practice through the harmonious properties of both sources by making a combination that can be used for decreasing the enormous use of chemical fertilizers and accreting a balance between fertilizer inputs and crop nutrient requirement, maintaining the soil fertility, optimizing the level of yield, maximizing the profitability, and subsequently reducing the environmental pollution. Lastly, INM is a tool that can offer good options and economic choices to supply plants with a sufficient amount of nutrients in need and can also reduce total costs, create favorable soil physiochemical conditions and healthy environment, eliminate the constraints, safeguard the soil nutrient balance, and find safety methods to get rid of agriculture wastes.
\end{abstract}

\section{Introduction}

The main challenges facing agriculture planners and farming decision makers in the coming few years' lies in vision world without hunger and zero poverty intensified by rising standards of living of rural regions, where the majority of poor people live and their full dependence on agriculture for living to fulfill their food demands [1]. The key to eliminate the current suffering lies in the creation of a strategic plan that enhances prosperous farming and enables farmers themselves to achieve agricultural growth, reduce poverty, and sustain high returns.

Thus, the main challenge in the forthcoming few years lies in the following question. Can agriculture provide the world population with all food needs which are expected to exceed 7.5 billion by the year 2020? [2]. With the view of an increase in land scarcity and water shortage, most of the agriculture plans depend on the use of chemical fertilizers and the production of new high-yielding crop varieties. Yet, both components are much expensive and will lead to higher pressure and more responsibilities for the financial investments and consequently will lead to an increase in the total costs. Meanwhile, the price of fertilizers increases, year by year, due to the higher amount of fertilizers needed in the second and third seasons as compared with that in the first season to maintain the current yield production at economical level. Despite the increase in the quantity of fertilizer application, a part of applied fertilizers and soil native nutrients were already consumed by the current and previous crops, especially in the case of intensive agriculture, where two to three crops are annually cultivated. Moreover, application of inorganic fertilizers is not a pragmatic option for many poor farmers in different regions worldwide, because many poor farmers do not have enough money to pay 
the claim of fertilizer price, besides its scarcity and unavailability in times of need.

Since ancient times, farmers have known that soil health can be restored by applying organic manure; accordingly, they used to apply farmyard manure regularly and directly after crop harvest. Consequently, the custom of using organic manures after harvesting has been coupled with restoration of soil health and improvement of physical, chemical, and biological properties of soil, particularly in marginal soils, which are already suffering from low organic matter and low native nutrient content, low productivity, and limitations and unavailability of essential nutrients [3-7].

Additionally, the organic farming system provides organic food, which is preferred by many customers regardless of higher prices. In this context, organic fertilizers, also due to their slow release, have greater residual effect on subsequent crops than inorganic nutrient, which is quickly lost by water leaching and runoff to underground water. Recently escalated calls emerged invited farmers and agriculture specialists to change their awareness towards substituting a part of inorganic fertilizers by cheaper, more sustainable, higher nutrient use of efficient, and eco-friendly nutrients, which are originated from natural resources (Compost), under the bold title of using integrated nutrient management (INM).

Under the heading of INM practices, many subheadings can be introduced, including the use of farmyard manures, natural and mineral fertilizers, soil amendments, crop residues, and farm waste recycling, agroforestry, green manures, and compost [6-11].

In contrast, some researchers have concluded that the effects of organic manures do not always have positive contribution, and some organic materials may indeed be inhibitory to plant growth, perhaps due to the presence of high levels of phytotoxins and high $\mathrm{C} / \mathrm{N}$ ratio, particularly in organic materials which are immature $[12,13]$.

Thus, the recycling of organic wastes, by the farmers themselves, may be a valuable and acceptable option for many of agriculture planners and numerous farmers to overcome the traditional methods of organic waste disposal, with or without the slight risk to the plants, groundwater or ecological pollution, and human health to achieve the best use of existing natural resources [6, 14-16].

The key component of the INM goal is to reach the most effective and homogeneous combination that could lead to good management and be an effective target of the fertilizers, sufficient and balanced use of their quantity and quality, and be straightforwardly uptaken by plants for higher yield without jeopardizing soil native nutrients or polluting the environment. It is ultimately viable to achieve such a target through the wise application of integrated nutrient management (INM) approach, which is known as a balanced mixture of organic, inorganic, and bioorganic microorganisms in combinations in different practices [17]. Also, it can improve all the characteristics of molecule absorption of macronutrients (NPK) and micronutrient inputs. In addition, it can match the crop nutrient requirements and alleviate the constraints of nutrient deficiency without any harmful effects in the environment and products. In contrary, in the case of mismanagement, it always leads to soil degradation, nutrient deficiency, and quick soil runoff [7].

Integrated nutrient management is also described as the technique of using minimum effective dose of sufficient and balanced quantities of organic and inorganic fertilizers in combination with specific microorganisms to make nutrients more available and most effective for maintaining high yields without exposing soil native nutrients and polluting the environment. Furthermore, many benefits can also be gained from using integrated nutrient management. INM can act as the driving forces, able to support the plans of converting marginal lands into productive ones, therefore fulfilling the strategy agenda of increasing cultivated land.

Although many researchers and specialists might find themselves surprised by the results of INM practices, farmers are still in need of great efforts and also additional assistance from many different disciplines, viz., scientific researchers, extension specialists, government sectors, and NGOs, to make them well known and able to recognize whole aspects of such practice, for example, training programs aim at increasing the basic knowledge of plant requirements for the optimum level of yield production. In the same respect, farmers are also in need to know which form of plant nutrients can be combined with each other to achieve the maximum nutrient-use efficiency and how these supplies can be integrated to obtain highest productivity levels within acceptable economic returns and satisfactory environmental impacts. Also, the integration between different disciplines is also necessary [18], in various spheres, such as plant breeding, agronomy, soil science, plant nutrition, plant protection, and agricultural engineering.

In addition, intensification of the efforts of extension specialists who are able to transfer research results into practical recommendations, besides government sectors and NGOs, who are the main reasons for supporting the future success of these technologies and creating responsible entities, will be able to market organic products in an extensive level.

In conclusion, integrated nutrient management is a tool which can offer good options and economic choices to supply plants with sufficient amounts of most macro- and micronutrients and also can reduce the dose of chemical fertilizers, create favorable soil physiochemical conditions and healthy environment, eliminate the constraints, safeguard the soil nutrient balance in the long run to an optimum level for sustaining the desired crop productivity, and find safety methods to get rid of agriculture wastes $[6,7,19-26]$.

\section{Literature Summary}

Global food production needs to be increased at least by $70 \%$ over the current level by 2050 to meet the increase in food demands, which rapidly increases as a result of overpopulation $[27,28]$. To achieve this challenging target, agriculture must grow significantly, in consideration of the factors that contribute to increase the yield production, which are 
already reduced or tend to reduce, since they are placing unprecedented pressure on the natural resources.

Achieving food security is a significant challenge facing agricultural development worldwide in addition to the option of solving highly critical problems to ensure alleviation of poverty. Realizing food security and agriculture sustainability is urgently required; therefore, improving many agronomic approaches, which have drastic effects on crop growth and yield, e.g., soil nutrient content, crop nutrient requirements, and soil nutrient balance, is necessary [29]. Among various practices followed by many farmers, some are in need of some improvement, particularly having bad habits regarding the use of a large amount of fertilizers under the inherited knowledge that without applying a large amount of fertilizers they do not maintain high yields. Such irresponsible practices, which are accepted by many farmers, result in the loss of most fertilizers applied and cause some environmental problems and raise the overall costs. Moreover, continuous use of synthetic fertilizers generates serious problems of soil nutrient deficiency and food contamination and damages soil physiochemical properties through the increase of soil acidity, which leads to hasty deterioration soil health, productivity, and both stability and sustainability $[6,7,30-36]$.

In spite of the fact that the application of chemical fertilizers has more advantages than disadvantages, it does not always mean that an increase in crop production must be obtained after their application, because a part of the added fertilizers may not be utilized by crop, as it may temporally remain in the soil or may be lost through volatilization or by leaching to underground water and then result in serious problems and dangers and becomes a source of environmental pollution [29, 37-42]. Considering the abovementioned reasons and in addition to high costs and declining profitability, scarcity, and leaching down to the root zone, groundwater contamination becomes the cause of diseases.

Recently, farmers and agricultural specialists recognize that further application of inorganic fertilizers does not mean that an increase must be induced, and then they realize the importance of soil fertility through the application of organic fertilizers, that are available and inexpensive and can be used solely or in combination with other available organic or inorganic resources to enhance the soil fertility and bring about higher crop production, without having any undesirable impacts on the environment [33, 34, 43-46].

Concerning the basic materials which can be used in the INM system, several investigators discovered that various materials can be used as a constituent of INM combinations, viz., farmyard manures, natural and mineral fertilizers, soil amendments, crop residues and farm waste recycling, agroforestry, green manures, and compost $[6,7,23,47]$. Such materials are generally seen as a key practice in the ecofriendly system to ensure sustainable production and safety food production [37, 48-60].

However, recycling of organic wastes into compost is a complex field practice that needs more labors and may lead to raise the labor and total costs. Yet, in comparison with the many gains that can be attained in the long run such as improving the soil health, ensuring safety of the food produce to guarantee that the environment will become satisfactory and acceptable technique for many farmers, agriculture specialists and agriculture planners alike [6]. Thus, the application of organic fertilizers leads to restoration of the soil health and maintains the productivity for long period; regretfully at field scales, the sole application of organic fertilizers to sustain the crop yield at economic level cannot be reliable. Therefore, it must be applied in combination with other fertilizers, which are derived from inorganic sources to meet the crop nutrient requirements.

Currently, the goal of interests of most researchers needs to be modified; the main issue of the most critical researches must be included in managing nutrient programs to provide a safe food supply free from pollutants or at least which contains minimum level of agrochemical contaminants, furthermore guaranteeing an environment without pollution or at least a lower level of pollution which is one of the huge challenges of the $21^{\text {st }}$ century $[6,7,22,23]$. Therefore, the great challenges have been to optimize the nutrient supplies to maintain high nutrient-use efficiency, refine the natural resources, modify the agriculture practices to achieve more grain yield per unit area, without jeopardizing the soil and natural resources, and improve the water use efficiency to produce more crops per drop. All of these are the most important goals, which can be achieved by the implementation of INM program not only at the present time but also in the near future.

Integrated nutrient management (INM) is a scheme that refers to a safest way to dispose off crop residues and produce high-quality compost by a balanced and integrated use of both sources of fertilizers together in combinations (organic and inorganic fertilizers) for maintaining soil fertility and providing plants with an optimum level of nutrients required over all of cycle life to sustain the yield productivity. The key component of INM system includes the following items:

(1) Considerable attention must be focused on all possible nutrient sources that can be used as a tool of nutrient sources in planning nutrient input programs for optimizing nutrient-use efficiency and high yield production

(2) The forms and quantities of soil nutrient contents in the root zone, which is known as soil balance and its availability to cover crop requirements (spatially and temporally)

(3) Minimizing nutrient losses, especially in the intensive agriculture system [61, 62]

(4) Taking all factors affecting the plant/nutrient relationship into consideration to achieve high yield production, which is the main objective and the major gain of the application of integrated nutrient management (INM), water use efficiency, grain superiority, high economic return, and sustainability [62]

Additional benefits also can be gained, i.e., produce healthy food free from contaminants and chemical residues, 
which is currently accepted and preferred by many customers due to the fact that they are safer and healthier compared with products which are conventionally produced under the sole application of synthetic fertilizers, regardless of their high price $[63,64]$. Furthermore, adopting such practice also had a contribution and remarkable residual effect on yield and yield component characters of the succeeding crop [65-70].

In addition, the studies of Kumar and Ahlawat [71], Alam et al. [72], Zingore et al. [73], Schulin et al. [74], Khoshgoftarmanesh et al. [11], Sánchez [75], Marschner et al. [76], Nawab et al. [41], Zhang et al. [23], Malika et al. [42], and Selim and Al-Owied [6] also came nearly to the same deduction which was mentioned previously and originated to the conclusion that integrating the nutrient management of organic and inorganic sources alongside with biofertilizers is the best way to get maximum benefits from the fertilizer application, particularly in the areas where nutrients are low or limited or in unavailable form; otherwise, some troubles will appear regarding the nutrient uptakes to sustain higher yield and maintain soil health. Furthermore, a part of the applied organic manure is being left with a high amount of crop residue after harvesting to the succeeding crop, and these materials will quickly decompose and turn into high-quality compost, which can improve the soil nutrient content and share in building soil organic matter, which protects the soil from erosion $[6,77,78]$. With widely predictable benefits from integrated plant nutrient management, it is necessary to make some adjustments in the traditional nutrient strategy plan; with particular attention to soil nutrient balance, and also, special consideration must be focused on the fact that native soil fertility is certainly difficult to be regained once again by application of fertilizers $[7,79-81]$.

Agriculture is a dynamic sector, affected by many variable factors, viz., different agroecological zones and types of soil texture, followed by farming practices, technologies, and variables in commodity markets. Furthermore, crops have different fertilizer needs and different use efficiencies; thus, an urgent priority must be done to look again at the fertilization programs when planning new soil reclamation agendas. Predictable satisfactory yield production will be produced by following integrated nutrient programs and could also eliminate the constraints, sustain the food security, guarantee the soil nutrient balance with magnificant benefits to succeeding crop [82-84], sustain the economic yield with little effect on native soil fertility, and minimize the risk in the environment pollution $[7,21-24,85,86]$.

Therefore, this review article discusses the remarkable contributions of integrated nutrient management accessible in the previous literature review under three main topics:

(i) Definitions, concepts, objectives, constraints, and advantages of INM

(ii) The relationship between INM and a number of factors that are affected on sustainable agriculture

(iii) The main value outcome from the application of INM

\subsection{Definitions, Concepts, Objectives, Constraints, and Advantages}

2.1.1. Definitions. Fertilizers are usually classified, according to the source driven into two main categories. The first one is the organic source (natural) and the second is inorganic source (mineral or synthetic or manmade). Integrated nutrient management (INM) is one of the agronomic practices aiming at the usage of the harmonious properties of both sources by making a combination that can be used for decreasing the enormous use of chemical fertilizers and accreting a balance between fertilizer inputs and crop nutrient requirement options, which can maintain the soil fertility, restore the soil health and continuous supply of plant with nutrient requirements to obtain an optimum level of yield production, maximize the profitability, and subsequently reduce the environmental pollution $[6,7,23,87,88]$. In conclusion, the definition of integrated nutrient management is a low-to-no-cost-effective technology for restoring soil health, as long as they can be produced and used within a same place.

2.1.2. Concepts. Integrated nutrient management is a practice that combines old and modern techniques of fertilizer use and nutrient management. The idea of INM depends on a number of factors, including harmony in nutrient properties, a balance between crop nutrient demands, what sort of nutrient, in general, is available in soil and in the farmer's hand, information and skills about the most suitable nutrient can be harmonized in combination, and which materials can be safely used that lead to increase nutrient-use efficiency. Additionally, it is a method and a way of disposing organic wastes safely and also an effective method of recycling wastes into goodquality compost $[6,89]$. The key components of the INM concept include the following: increasing the farmer's awareness about the valuable use of INM practices, inviting them to forget the excessive use of chemical fertilizers, and encouraging them to focus on long-term plan for sustainable agriculture. Moreover, farmers must have greater consideration for environmental impacts and producing safety food rather than only focusing on profit, which can be obtained. It must always be remembered that food safety is much preferred by many customers, regardless of the price, and it can raise the farmer's returns by following such practices.

2.1.3. Objectives. The main objective of the integrated nutrient management is to maintain economic yield for a long period with little effect on native soil fertility and environmental pollution, making some changes in farmer's awareness toward the eco-friendly technique (organic farming system) for producing healthy food free from contaminants and insuring satisfactory economic returns. 
2.1.4. Constraints (Difficulties). Soil corrosion, mining, degradation, and also loss of fertility are the main reasons leading to irreversible decrease of plant production and huge damage for sustainable agriculture. Therefore, to sustain soil health and return soil productivity is an urgent need to overcome the problem of low soil productivity. Serious efforts have been made including the promotion of more productive use of integrated nutrient management, which is an inessential portion in the organic farming system. In addition, considerable attention must be given to determine soil nutrient balance including nutrients absorbed by the current crop accompanied by great attention towards the requirement of the succeeding crop. Thus, continual assessment of the changes in the current soil fertility is necessary to determine nutrient loss through crop absorption, erosion, and leaching and to mirror soil balance, because quick depletion of soil fertility and reduction in soil organic matter will be expected [90, 91].

Additionally, there are some constraints facing the progress of the integrated nutrient management. Firstly, due to the difficulties in obtaining FYM and biofertilizers, some poor farmers have some trouble in obtaining organic manure as well as lack of knowledge, poor advisory services, and skills of recycling organic wastes to produce high-quality compost. Also, biotic or abiotic stresses are ranked to second series and the third will be the poor tillage, whereas the lack of equipment was ranked in the fourth succession. Also, the absence of the role of extension services and NGOs to support farmers and direct their attention to the importance of using integrated nutrient management and its benefits in conserving soil properties, soil nutrient balance, environmental impacts, and their role in increasing their profitability is a constraint. Finally, all of these could hardly be detected and could be added to the above snags.

2.1.5. Advantages. Preparing the soil for producing its maximum capacity is an important target and a complex process resulting from the solidarity of many factors, which largely depend on more than one factor to get the best benefits, among others, soil nutrient content which must not only be in an appropriate and accurate quantity but also be in an easy and available form for plant absorption at the right time of plant requirement. Thus, a good nutrient management package is a way to attain ideal growth and yield levels for most crops at different agroecological zones, with or without minimum risk in the environment (eco-friendly strategy) $[6,7,17,23,67,92,93]$.

This can also be described as a system involving a series of the following benefits:

(1) Systems can improve the soil nutrient natives and increase the solubility and availability of fertilizers to be used

(2) Use the harmonious behavior of nutrient supplies and making them match with the crop requirements

(3) Offer the nutritional balance to the crops and lessen the aggressive effects resulting from the opposite impact between nutrient fractions and nutrient imbalance

(4) Advance and sustain the physiochemical and biological functions of soil properties

(5) Reduce the rate of soil degeneration, water, and ecosystem by enhancing carbon confiscation and decreasing nutrient losses to ground and surface water forms and/or to environment pollution

(6) Minimize higher total costs of production and raise the farmer's returns (increasing profitability)

(7) Improve the resistance to both biotic and abiotic stresses

(8) An effective method of agricultural practices to ensure healthy food, covering population food demands alongside with many soil and environmental impacts, especially in countries with rapid growth in population

(9) Additional benefits can also be gained; it does not only save the total costs at the satisfactory level with an increase in crop production but also can be easily practiced by farmers; therefore, it is considered one of the most promising techniques in line with the future needs

(10) INM can have positive effects on the susceptibility or plant resistance against many types of biotic and abiotic stresses

(11) Following INM will enable to explore a larger volume of soil in order to access water and nutrients; additionally, improved root development enables the plant to absorb water from deeper soil layers and then reflect an increase in the ability of crops toward drought resistance

(12) Changes in awareness of farmers toward the climate changes from season to season, which have greater ecological impacts in order to produce safe food rather than achieving higher yield aiming at attaining higher profit

\subsection{Relationship between INM and the Effect of a Number of Factors on Sustainable Agricultural Production}

2.2.1. Integrated Plant Nutrient Management in Relation to Macro- and Micronutrients. Generally, most of the major studies regarding the effect of the application of macronutrients (NPK) are mainly focused on testing the rate of application, timing of application, varietal responses, and the effect of its integration with numerous agronomic practices. However, most of the studies related to the effect of micronutrient application have focused on yield quality traits or may also include methods of application, suitable for treating the problems of micronutrient deficiency $[33,70,89,94-96]$. Most of these studies suggested that application of the recommended dose of inorganic fertilizers is more important than being neglected in order to maintain the economic yield, especially in low-fertile soils $[61,62,95,97]$. Whereas the other investigators reported 
that, occasionally, the application of inorganic fertilizers may be the reason for prolonging growth period and also may be the cause of delayed flowering and physiological maturity by 1-2 weeks [98] and will lastly lead to a decrease in yield quantity and quality. Above all, imbalanced and continuous use of inorganic fertilizers may result in some problems in micronutrient deficiencies, which become major constraints on productivity, stability, and sustainability of soil health $[30,60,99]$. Therefore, INM becomes one of the most principle practices, which can replace the traditional methods, decreasing the nutrient losses and their harmful effects on the environment, while maintaining higher crop yield and advanced profits [100]. Considerable attention to the success of INM is related to the selection of a combination, which can provide plants with different nutrient sources in adequate amount at intervals agreeable with the plant requirements and also which plays a vital role in improving the nutrient-use efficiency and can achieve higher yields $[62,101]$. Also, integrated nutrient management practices may be the best way or dominant option for harmonizing the utilized totality of the farm wastes that can be used as plant nutrients. In addition, it is not only the most effective practice that can prevent nutrient deficiency but also strongly related to social issues, especially for poor farmers, who are unable to spend large investments in maintaining the soil fertility.

Although the combination of organic fertilizers with inorganics considered a stock of nutrients which can continuously supply the current crop with their requirements, it can also be considered as a scheme which has greater residual effect on subsequent crops than sole application of inorganic fertilizers, due to slow release of nutrients over time and its added value in soil organic matter content $[45,102]$.

In addition, most of current literature revealed that significant attention has been paid to determine the role of integrated nutrient management of organic and inorganic fertilizers on growth and yield, including the use of FYM, green manures, and biofertilizers [103-105]. In the same respect, the study of Hemalatha and Chellamuthu [106] on a long-term field experiment found that the continuous application of inorganic fertilizers alone reduces the soil organic carbon level due to low dry matter production and leads to reduction in the return of crop residues to the soil. Keeping these aspects in mind, excess or lack of essential nutrients $(\mathrm{N}, \mathrm{P}, \mathrm{K}, \mathrm{S}, \mathrm{Ca}$, and $\mathrm{Mg})$ and micronutrients is often called "limiting factors" because each one could limit the plant growth and cause serious problems in most of the accumulation processes of making the use of integrated nutrient management an essential factor and a main reason leading to sustainable agriculture.

Lastly, farmers and researchers cannot neglect the role of the soil microorganisms in controlling nutrient conversions, solubility, availability, release from the soil root zone to plant roots, and also the role in absorption and raising nutrient-use efficiency, which can be achieved by following the INM system $[8,107-112]$. An additional trend was also observed, a decrease in the losses of water and nutrients through leaching, runoff, volatilization, emissions, and immobilization [23], which resulted from an increase in the soil organic matter contents and improvement of soil physical and hydrological properties.

\subsubsection{Integrated Plant Nutrient Management in Relation to} Environmental Concern and Food Requirements. Since the early times of the 1990s, the increase of agricultural production for main food crops has been increasing or even tended to decrease, whereas the trend for global food production needs to increase to above 4 billion metric tons by 2050 to cover population needs which are rapidly increasing [28]. However, further increases in the farming production have been associated with negative impacts on global change, water scarcity, land degradation, erosion, and soil nutrient balance besides depletion of soil organic carbon and later soil runoff $[27,113]$.

Agricultural approaches are the largest contributors to these emissions. Tremendous increase, which has rapidly emerged in the recent years, is mainly due to the huge use of synthetic fertilizers and pesticides, especially in the case of the intensive agricultural system $[23,114]$. Thus, the use of chemical fertilizers particularly nitrogen, phosphorus, and potassium (NPK) is the essential factor and main reason leading to environmental pollution and land erosion because of their perpetual uses for long time in some developing countries $[115,116]$. In addition, the consumption of synthetic fertilizers has risen globally by $49 \%, 19 \%$, and $33 \%$ for nitrogen, phosphorus, and potassium, respectively [23].

Some of the current investigations reported that the intensive use of synthetic fertilizers and pesticides did not have a significant contribution in the yield increase; this may be due to more than one factor, viz., great nutrient losses through leaching, runoff, volatilization, and releases and immobilization or may be owing to low nutrient-use efficiency. Thus, the reverse habits are necessary and also are essential in devising an agriculture strategy plan to find out a way that enables to produce higher yield production for long-term periods, encourages conservation natural resources, ecological impacts, and global climate change alleviation and adaptation, also matching with the other agricultural programs aiming at increasing the production and ensuring the environment. Accordingly, it is high time to search for innovative practices which can guarantee higher yield productions with or without minimal risks or further deterioration of our environment. INM technique can thus play this role and remain the most effective way to achieve the food security, improve the environmental quality, and meet the growing food demand worldwide without any bad effects, especially in countries having rapid growth population.

Integrated nutrient management (INM) is also a practice that has much significantly shown impacts by decreasing the chemical application through a combination of inorganic and organic fertilizers either with or without biofertilizers that could minimize the nutrient applications and then lessen their nutrient requirements, reduce food contamination $[6,7,17,23,62,67,92,93]$. 
Lastly, INM is a simple system that can create a favorable soil condition, able to provide plants with sufficient, efficient, and sustainable nutrient source and also is a promising strategy that has made considerable contributions to lessen the negative environmental impact, boost both the quantity and quality traits of the global food supplies, and increase the land expansion with the plan of sustainable and economical agricultural development $[18,115]$.

\subsubsection{Integrated Plant Nutrient Management in Relation to} Soil Structure and Water Use. Recently, many findings highlighted that the relationship between soil structure and water conserving or water uses liner and largely depends on many factors, among these, soil organic matter, both quality and quantity, due to the fact that soil organic matter is considered the primary peacekeepers of most of soil properties, which are the bases of soil quality physically (structure), chemically (nutrition), and biologically (microorganisms). Brady and Weil [117] reported that $100 \mathrm{~kg}$ of dry soil that contains $1 \%$ organic matter can hold $30 \mathrm{~kg}$ of water, whereas soil with $5 \%$ organic matter can hold $195 \mathrm{~kg}$ of water. In the same context, several investigators came nearly to the same conclusion $[49,53,118-121]$ and also the relationship between soil structure and soil productivity [30].

Numerous investigators also concluded that the organic and inorganic fertilizers in combination with biofertilizers is not only used as a source of nutrients but also can be used as soil amendment to improve the soil organic carbon (SOC) content, aggregate stability, and moisture-retention capacity [110, 122-125].

Therefore, any further improvement in soil structure creates a favorable condition for plant water relationship without having any undesirable impact on the environment, for example, integrated nutrient management can improve the soil organic carbon, which is an important indicator of soil structure and can directly indicate the state and type of soil quality and soil fertility and is also a proof of the possibility of agriculture sustainability due to the sunny roles in improving the soil physical properties, viz., nutrient availability, moisture retention, cation-exchange capacity, soil $\mathrm{pH}$, microbial community and activity, bulk density, and aeration [126-129]. Whereas other studies reported that application of organic manures with chemical fertilizers through integrated nutrient management system has an effective role in improving the physiochemical soil properties, that leads to an improvement in water infiltration, water-holding capacity, and water flow down and increase in soil field capacity, which consequently improve the economic water use and water use efficiency and leads to more water conservation without reversible effects on crop productivity $[32,35,130,131]$.

In addition, further improvement in soil $\mathrm{pH}$ creates a favorable condition for macro- and micronutrient absorption. Truog [132] indicated that $\mathrm{pH}$ is a critical factor for plant nutrient absorption; the largest advantages in the uptake of macro- and micronutrient by the plants was noticed in the soil $\mathrm{pH} 7.0$, even at a minimum recommended dose of synthetic fertilizers. Currently, several investigators also came to similar conclusions Boschetti et al. [133] and Marschner [96] suggested that acidification and alkalization in the rhizosphere are the dominant factors affecting the solubility and availability of soil nutrients. For example, in alkaline soils where higher $\mathrm{pH}$ is prevailing, marked decrease in $\mathrm{Fe}, \mathrm{Zn}, \mathrm{Mn}$, and $\mathrm{Cu}$ absorption was observed, because these elements are highly correlated to lower $\mathrm{pH}$ [96, 134-136].

Recently, noticeable quantitative and qualitative changes in field management practices are particularly related to the use of organic manure and chemical fertilizers along with biofertilizers. These changes are generally beneficial for improving the physical, chemical, biological, and hydrological properties of the soil, which are reflected in a significant rate in mitigation; the irreversible adverse effect of the drought stress make up a significant portion of water conservation and soil degradation and the main effect may be updegraded soil class [54, 117, 137-139]. In the same respect, previous studies indicated that high attention must be given on the fact that some fields have poor response to nutrient unsystematic application of fertilizers $[22,24]$.

\subsubsection{Integrated plant Nutrient Management in Relation to} Plant Growth and Crop Yield. Plant growth is influenced by many factors, e.g., application of the recommended and ideal dose of inorganic and organic fertilizers, which is an essential option and important factor for enhancing the crop growth and nutrient uptake as well as a vital component in supporting the crop life cycle and yield potential [140, 141]. Therefore, superfluous additions of fertilizers does not always mean that an increase in crop production must occur; a part of added fertilizers may be not absorbed by the crop and mostly remain in the soil or may be lost through volatilization or by leaching to underground water, and then become dangerous and a source of environmental pollution.

Several investigations indicate that INM has remarkable benefits and play a potential role not only on crop growth but also on sustainable development of agriculture involving environmental impacts. It is well known that a rapid decline in soil fertility which leads to low productivity is related to many factors and occasionally closely linked to irresponsible practices followed by farmers, among these, continuous and intensive use of the cropping system, excessive use of chemical fertilizers, and negligence of soil nutrient balance in planning agriculture programs [9], and intensive cultural practices [142] and ignoring the application of organic manures solely or in combination with inorganic fertilizers $[6,25,143]$. Therefore, when managing the agriculture strategy, significant attention must not only be given to fertilization programs only but also to the sources of nutrients which are matching, homogeneous, and mixed in such a combination that they are available for plant absorption and cover all of the crop needs.

Success of INM relies on a number of factors, including appropriate right combination, right dose, and right form 
and application at right time of plant need. The integrated use of organic, chemical, and biofertilizers also has an effective role in improving the soil properties $[69,144,145]$, enhancing the nutrient-use efficiency, decreasing the nutrient loss, minimizing the crop nutrient requirement, and increasing the cation exchange, water storage capacity, and service in sustaining higher yield [11], and improving the phytoavailability of micronutrients in soil and their uptake by plants $[70,74]$. All of these may also work together and play a notable role in crop quality. In addition, having an effective role, in general, on plant vigor contribution, particularly which are related to root development, water and nutriment uptake, and dry matter accumulation. Results of Goyal et al. [69], Sushila and Gajendra [146], Wells et al. [147], Camara et al. [148], Mohammad et al. $[128,149]$, Bolan et al. $[144,145,150]$, Brady and Weil [117], Hati et al. [151], Carrera et al. [152], Deksissa et al. [153], Odlare et al. [154], Zhang et al. [23], Selim and ALOwied [6] and Selim [7] indicate that INM plays an essential role in improving the plant growth in terms of plant height, dry weight accumulation, leaf area, LAI, LAD, and CGR, which directly have positive effects in raising the crop productivity per unit area and consequently leading to an increase in water use efficiency, water conservation, and economic water use. Owing to the effect of INM on most of crop growth parameters, high crop yields can be achieved even without further application of NPK rates above the recommended dose of the home-grown area $[111,112,155]$.

In this domain, strong and conclusive indication reported previously by many researchers indicate that INM practice can be an effective practice and eco-friendly approach to produce greater yield production and maintain satisfactory profitability to farmers $[7,156-162]$.

\subsubsection{Integrated plant Nutrient Management in Relation to} Succeeding Crops. The bulk of the literature highlighted that long-term use of organic and inorganic fertilizers in combination with biofertilizers indicates a better and effective option to get maximum benefits from the soil to the current crops and occasionally may be extended to the succeeding crop. Many results also concluded that the residual effect of the bioorganic farming system may double the yield of subsequent cereal crops [65]. Furthermore, the papers $[7,11,66-68,72,90,91]$ suggested that INM is an important tool for assessing the nutrient reserve in soils, restoring the soil health, and the most effective management strategy to advance the biological and physiochemical properties of soil, which are vital components in assessing yield and yield contributing components of both preceding and succeeding crops. Such an effect on soil biological properties may be due to the role of microorganisms not only in increasing nitrogen fixation but also in improving the availability and mobility of phosphorus, potassium, and iron, thus providing the plants with essential components needed for the process of plant development and yield productivity while remediating the soil structure by improving its accumulation and constancy $[7,69,70,74,91]$.
2.3. Main Values of INM. The points below are considered the main principles of INM to be considered in planning the integrated nutrient management strategies:

(1) Adopting INM practices must be compatible with the local farming system, for example, field biological condition (weeds, insects, and diseases), soil texture, irrigation services, and equipment's available and climatic conditions.

(2) Using both sources of nutrients optimizes fertilizer input, increases the use efficiency by crops and then lessens their nutrient requirements and reduces food contamination, environmental pollution, and total costs.

(3) Corresponding soil nutrient supplies with crop demand spatially and temporally in order to conserve native soil contents.

(4) INM practice reduces the fertilizer loss, improves the crop potential, and increases the profitability.

(5) In long term, it improves the physiochemical properties of the soil (biological and hydrological properties).

(6) Applying INM practice on root zone, where the most important process between plant and soil occur, is a "bottleneck" controlling nutrient conversions, solubility, availability, and release from soil to plant roots and absorption. Such an exercise can respond to maximize the biological potential through enhancing the soil microorganism's activity.

\section{Conclusion and Recommendation}

Challenges in the forthcoming few years lie in the debate that agriculture can provide the world population with food in need, which annually exceeds more than 4 billion ton. Therefore, achieving higher yield per unit area and more crops per drop are the main challenges facing researchers, agricultural specialists, and farmers worldwide and also is the main option of solving highly critical problems of alleviation poverty. In this domain, fewer response to the recommended dose of chemical fertilizers and low response of some fields to fertilizer application are the main constrains and bottlenecks not only for low production but also deteriorates the soil health. Integrated nutrient management is a tool which can offer good options and economic choice to supply plants with a sufficient amount of most macro- and micronutrients and also can reduce the dose of chemical fertilizers, create favorable soil physiochemical conditions and healthy environment, eliminate the constraints, safeguard the soil nutrient balance in the long run, generate an optimum level for sustaining the desired crop productivity, and lastly find safe methods to get rid of agriculture wastes. Additional offer also can be gained, a part of the applied organic manure is left with a high amount of crop residue after harvesting to the succeeding crop; and these materials will be quickly decomposing and turn to high quality compost, which can improve soil properties and share in building soil organic matter, which is the main option of 
protecting soil from erosion. Lastly, the interest of agriculture specialists and farmers must be turned toward a simple technique of integrated nutrient management, which is an acceptable option, a cost-effective practice, can be easily followed by farmers, and an eco-friendly approach, reducing the claim of fertilizers and could produce greater yield production with better quality traits and maintain satisfactory profit.

\section{Additional Points}

Highlights. What is integrated plant nutrient management? What is the matter? Definitions, concepts, objectives, principles, advantages, difficulties, relationships, and the main values. How can integrated plant nutrient management improve agriculture sector? Can the long-term usage of integrated nutrient management rationalize the huge use of chemical fertilizers; restore soil health; and increase finishing return? Does integrated plant nutrient management have a remarkable contribution on mitigation agriculture constrains, viz., climate changes, environmental pollution, and decreased production costs? Magnitude role of integrated plant nutrient management in land reclamation programs to close the wide gap between total global production and growing global food demands. Do we urgently need integrated plant nutrient management to maintain agriculture and environment pollution or not?

\section{Conflicts of Interest}

The authors declare that they have no conflicts of interest.

\section{References}

[1] T. Wheller and J. Braun, "Climate change impacts on global food security,” Science, vol. 341, pp. 508-513, 2013.

[2] FAO, "FAOSTAT FAO database-statistics division food and agriculture organization of the United Nations, Rome," 2012, http://faostat.fao.org/.

[3] P. A. Adeoye, S. E. Adebayo, and J. J. Musa, "Growth and yield response of cowpea (Vigna unguiculata) to poultry and cattle manure as amendments on sandy loam soil plot," Agricultural Journal, vol. 6, no. 5, pp. 218-221, 2011.

[4] M. Siavoshi, S. L. Laware, and S. L. Laware, "Effect of organic fertilizer on growth and yield components in rice (Oryza sativa L.)," Journal of Agricultural Science, vol. 3, no. 3, 2011.

[5] G. Rahmann, M. R. Ardakani, P. Bàrberi et al., "Organic agriculture 3.0 is innovation with research," Organic Agriculture, vol. 7, no. 3, pp. 169-197, 2016.

[6] M. M. Selim and A.-J. A. Al-Owied, "Genotypic responses of pearl millet to integrated nutrient management," Bioscience Research, vol. 14, no. 2, pp. 156-169, 2017.

[7] M. Selim, "Potential role of cropping system and integrated nutrient management on nutrients uptake and utilization by maize grown in calcareous soil," Egyptian Journal of Agronomy, vol. 40, no. 3, pp. 297-312, 2018.

[8] S. K. Rautaray, B. C. Ghosh, and B. N. Mittra, "Effect of fly ash, organic wastes and chemical fertilizers on yield, nutrient uptake, heavy metal content and residual fertility in a ricemustard cropping sequence under acid lateritic soils," Bioresource Technology, vol. 90, no. 3, pp. 275-283, 2003.
[9] Z. Shah, S. H. Shah, M. B. Peoples, G. D. Schwenke, and D. F. Herridge, "Crop residue and fertiliser $\mathrm{N}$ effects on nitrogen fixation and yields of legume-cereal rotations and soil organic fertility," Field Crops Research, vol. 83, no. 1, pp. 1-11, 2003.

[10] Z. Shah and M. I. Ahmad, "Effect of integrated use of farm yard manure and urea on yield and nitrogen uptake of wheat," Journal of Agricultural and Biological Science, vol. 1, pp. 60-65, 2006.

[11] A. H. Khoshgoftarmanesh, R. Schulin, R. L. Chaney, B. Daneshbakhsh, and M. Afyuni, "Micronutrient-efficient genotypes for crop yield and nutritional quality in sustainable agriculture. A review," Agronomy for Sustainable Development, vol. 30, no. 1, pp. 83-107, 2010.

[12] C. M. Craft and E. B. Nelson, "Microbial properties of composts that suppress damping-off and root rot of creeping bentgrass caused by pythium graminicola," Applied and Environmental Microbiology, vol. 62, no. 5, pp. 1550-1557, 1996.

[13] M. de Bertoldi, "Production and utilization of suppressive compost: environmental, food and health benefits," in Microbes at Work From Wastes to Resources, H. Insam, I. H. Franke-Whittle, and M. Goberna, Eds., pp. 153-170, Springer, Berlin, Germany, 2010.

[14] R. T. Haug, The Practical Handbook of Compost Engineering, Lewis Publishers, Boca Raton, FL, USA, 1993.

[15] A. C. Gaur and G. Singh, "Recycling of rural and urban wastes through conventional and vermicomposting," in Recycling of Crop, Animal, Human and Industrial Wastes in Agriculture, H. L. S. Tandon, Ed., pp. 31-35, FDCO, New Delhi, India, 1995.

[16] R. A. Abdel-Aziz and F. N. Al-Barakah, "Composting technology and impact of compost on soil biochemical properties," Arab Gulf Journal of Scientific Research, vol. 23, no. 2, pp. 80-91, 2005.

[17] B. H. Janssen, "Integrated nutrient management: the use of organic and mineral fertilizers," in The Role of Plant Nutrients for Sustainable Crop Production in Sub-saharan Africa, H. van Reuler and W. H. Prins, Eds., pp. 89-105, Ponsen and Looijen, Wageningen, Netherlands, 1993.

[18] W. Wu, C. Li, B. Ma, F. Shah, Y. Liu, and Y. Liao, "Genetic progress in wheat yield and associated traits in China since 1945 and future prospects," Euphytica, vol. 196, no. 2, pp. 155-168, 2014.

[19] Y. N. Song, F. S. Zhang, P. Marschner et al., "Effect of intercropping on crop yield and chemical and microbiological properties in rhizosphere of wheat (Triticum aestivum L.), maize (Zea mays L.), and faba bean (Vicia faba L.)," Biology and Fertility of Soils, vol. 43, no. 5, pp. 565-574, 2007.

[20] P. Garbeva, J. D. van Elsas, and J. A. van Veen, "Rhizosphere microbial community and its response to plant species and soil history," Plant and Soil, vol. 302, no. 1-2, pp. 19-32, 2008.

[21] X. Li, J. Lu, L. Wu, and F. Chen, "The difference of potassium dynamics between yellowish red soil and yellow cinnamon soil under rapeseed (Brassica napus L.) rice (Oryza sativa L.) rotation," Plant and Soil, vol. 320, no. 1-2, pp. 141-151, 2009.

[22] S. Zingore, P. Tittonell, M. Corbeels, M. T. Van Wijk, and K. E. Giller, "Managing soil fertility diversity to enhance resource use efficiencies in smallholder farming systems: a case from Murewa District, Zimbabwe," Nutrient Cycling in Agroecosystems, vol. 90, no. 1, pp. 87-103, 2011.

[23] F. Zhang, Z. Cui, X. Chen et al., "Integrated nutrient management for food security and environmental quality in China," Advances in Agronomy, vol. 116, pp. 1-40, 2012. 
[24] P. Tittonell and K. E. Giller, "When yield gaps are poverty traps: the paradigm of ecological intensification in African smallholder agriculture," Field Crops Research, vol. 143, pp. 76-90, 2013.

[25] S. Samreen, Z. Shah, and W. Mohammad, "Impact of organic amendments on soil carbon sequestration, water use efficiency and yield of irrigated wheat," Biotechnology, Agronomy, Society and Environment, vol. 21, no. 1, pp. 36-42, 2017.

[26] Y. Wang, Z. Zhao, J. Li et al., "Does maize hybrid intercropping increase yield due to border effects?" Field Crops Research, vol. 214, pp. 283-290, 2017.

[27] J. Bruinsma, "The resource outlook to 2050: by how much do land, water, and crop yields need to increase by 2050?," in Expert Meeting FAO, J. Bruinsma, Ed., FAO, Rome, Italy, 2009.

[28] FAO, Declaration of the World Summit on Food Security, FAO, Rome, Italy, 2009.

[29] A. M. Ali, M. R. Alam, M. S. H. Molla, and F. Islam, "Crop productivity as affected by fertilizer management options in Boro-T.aman cropping pattern at farmer's fields," Bangladesh Journal of Agricultural Research, vol. 35, no. 2, pp. 287-296, 2010.

[30] R. L. Yadav and M. C. Meena, "Available micronutrient status and their relation with soil properties of Degana soil series of Rajasthan," Journal of the Indian Society of Soil Science, vol. 57, no. 1, pp. 90-92, 2009.

[31] B. Kacar and A. Katkat, Plant Nutrition/Nobel Publication No. 843, Science and Biology Publication, Ankara, Turkey, 2009.

[32] H. Yolcu, H. Şeker, M. K. Gullap, A. Lithourgidis, and A. Güneş, "Application of cattle manure, zeolite and leonardite improves hay yield and quality of annual ryegrass (Lolium ultiflorum Lam.) under semiarid conditions," AJCS, vol. 5, pp. 926-931, 2011.

[33] J. K. Suge, M. E. Omoniyi, and E. N. Omani, "Effect of organic and inorganic sources of fertilizer on growth, yield and fruit quality of eggplant (Solanum melongena)," Achieves of Applied Science Research, vol. 3, no. 6, pp. 470-479, 2011.

[34] I. A. S. Gudugi, "Effects of cow dung and variety on the growth and yield of Okra (Abelmuschus esculentus L.)," European Journal on Experimental Biology, vol. 3, no. 2, pp. 495-498, 2013.

[35] R. I. Nazli, I. Inal, A. Kusvuran, A. Demirbas, and V. Tansi, "Effects of different organic materials on forage yield and nutrient uptake of silage maize (Zea mays L.)," Journal of Plant Nutrition, vol. 39, no. 7, pp. 912-921, 2015.

[36] G. Rasool, A. J. Wahla, M. Nawaz, and M. AbdurRehman, "Determination and evaluation of the effect of different doses of humic acid on the growth and yield of wheat (Triticum aestivum L.)," IOSR Journal of Agriculture and Veterinary Science (IOSR-JAVS), vol. 8, no. 2, pp. 5-7, 2015.

[37] M. A. Saleque, M. J. Abedin, N. I. Bhuiyan, S. K. Zaman, and G. M. Panaullah, "Long-term effects of inorganic and organic fertilizer sources on yield and nutrient accumulation of lowland rice," Field Crops Research, vol. 86, no. 1, pp. 53-65, 2004.

[38] J. Timsina, G. M. Panaullah, M. A. Saleque et al., "Nutrient uptake and apparent balances for rice-wheat sequences. I. Nitrogen," Journal of Plant Nutrition, vol. 29, no. 1, pp. 137-155, 2006.

[39] M. A. Saleque, J. Timsina, G. M. Panaullah et al., "Nutrient uptake and apparent balances for rice-wheat sequences. II. Phosphorus," Journal of Plant Nutrition, vol. 29, no. 1, pp. 157-172, 2006.
[40] J. Timsina, M. L. Jat, and K. Majumdar, "Rice-maize systems of South Asia: current status, future prospects and research priorities for nutrient management," Plant and Soil, vol. 335, no. 1-2, pp. 65-82, 2010.

[41] K. Nawab, P. Amanullah Shah, A. Rab et al., "Impact of integrated nutrient management on growth and grain yield of wheat under irrigated cropping system," Pakistan Journal of Botany, vol. 43, no. 4, pp. 1943-1947, 2011.

[42] M. Malika, M. R. Islam, M. R. Karim, A. Huda, and M. Jahiruddin, "Organic and inorganic fertilizers influence the nutrient use efficiency and yield of a rice variety BINA dhan7," Acad. Res. J AgrilSci Res, vol. 3, no. 7, pp. 192-200, 2015.

[43] J. A. Ogunwale, J. O. Olaniyan, and M. O. Aduloju, "Morphological, physio-chemical; and clay mineralogical properties of soils overlaying basement complex rocks in Ilorin East, Nigeria," Moor Journal of Agricultural Research, vol. 3, no. 2, pp. 147-154, 2002.

[44] A. R. M. Solaimam and M. G. Rabbani, "Effects of NPKS and cow dung on growth and yield of tomato," Bulletin of the Institute of Tropical Agriculture, vol. 29, no. 1, pp. 31-37, 2006.

[45] O. E. Omotayo and K. S. Chukwuka, "Soil fertility restoration techniques in Sub-sahran Africa using organic resources," African Journal of Agricultural Research, vol. 4, no. 3, pp. 144-150, 2009.

[46] L. B. Tonfack, A. Bernadac, E. Youmbi, V. P. Mbouapouognigni, M. Ngueguim, and A. Akoa, "Impact of organic and inorganic fertilizers on tomato vigor, yield and fruit composition under tropical andosol soil conditions," Fruits, vol. 64, no. 3, pp. 167-177, 2009.

[47] X.-T. Ju, G.-X. Xing, X.-P. Chen et al., "Reducing environmental risk by improving $\mathrm{N}$ management in intensive Chinese agricultural systems," Proceedings of the National Academy of Sciences, vol. 106, no. 9, pp. 3041-3046, 2009.

[48] J. M. Duxbury, "Long-term yield trends in the rice-wheat cropping system," Journal of Crop Production, vol. 3, no. 2, pp. 27-52, 2001.

[49] R. L. Yadav, B. S. Dwivedi, K. Prasad, O. K. Tomar, N. J. Shurpali, and P. S. Pandey, "Yield trends, and changes in soil organic-C and available NPK in a long-term rice-wheat system under integrated use of manures and fertilisers," Field Crops Research, vol. 68, no. 3, pp. 219-246, 2000.

[50] A. L. Bhandari, J. K. Ladha, H. Pathak, A. T. Padre, D. Dawe, and R. K. Gupta, "Yield and soil nutrient changes in a longterm rice-wheat rotation in India," Soil Science Society of America Journal, vol. 66, no. 1, pp. 162-170, 2002.

[51] P. B. S. Bhadoria and Y. S. Prakash, "Relative influence of organic manures in combination with chemical fertilizer in improving rice productivity of lateritic soil," Journal of Sustainable Agriculture, vol. 23, no. 1, pp. 77-87, 2003.

[52] A. P. Regmi, J. K. Ladha, H. Pathak et al., "Yield and soil fertility trends in a 20-year rice-rice-wheat experiment in Nepal," Soil Science Society of America Journal, vol. 66, no. 3, pp. 857-867, 2002.

[53] J. K. Ladha, D. Dawe, H. Pathak et al., "How extensive are yield declines in long-term rice-wheat experiments in Asia?" Field Crops Research, vol. 81, no. 2-3, pp. 159-180, 2003.

[54] S. Sarkar, S. R. Singh, and R. P. Singh, "The effect of organic and inorganic fertilizers on soil physical condition and the productivity of a rice-lentil cropping sequence in India," The Journal of Agricultural Science, vol. 140, no. 4, pp. 419-425, 2003. 
[55] S. Yadvinder, S. Bijay, J. K. Ladha et al., "Long-term effects of organic inputs on yield and soil fertilityin the rice-wheat rotation," Soil Science Society of America Journal, vol. 68, pp. 845-853, 2004.

[56] D. Jiang, H. Hengsdijk, T.-B. Dai, W. De Boer, Q. Jing, and W.-X. Cao, "Long-term effects of manure and inorganic fertilizers on yield and soil fertility for a winter wheat-maize system in jiangsu, China," Pedosphere, vol. 16, no. 1, pp. 25-32, 2006.

[57] W. A. J. M. De Costa and U. R. Sangakkara, "Agronomic regeneration of soil fertility in tropical Asian smallholder uplands for sustainable food production," The Journal of Agricultural Science, vol. 144, no. 2, pp. 111-133, 2006.

[58] P. K. Ghosh, M. C. Manna, D. Dayal, and R. H. Wanjari, "Carbon sequestration potential and sustainable yield index for groundnut- and fallow-based cropping systems," The Journal of Agricultural Science, vol. 144, no. 3, pp. 249-259, 2006.

[59] B. R. Taylor, D. Younie, S. Matheson et al., "Output and sustainability of organic ley/arable crop rotations at two sites in northern Scotland," The Journal of Agricultural Science, vol. 144, no. 5, pp. 435-447, 2006.

[60] S. Hossein and F. Ghooshchi, "Response of growth and yield of maize to biofertilizers in organic and conventional cropping systems," The International Journal of Agriculture and Crop Sciences, vol. 5, no. 7, pp. 797-801, 2013.

[61] X.-P. Chen, Z.-L. Cui, P. M. Vitousek et al., "Integrated soilcrop system management for food security," Proceedings of the National Academy of Sciences, vol. 108, no. 16, pp. 6399-6404, 2011.

[62] W. Wu and B. Ma, "Integrated nutrient management (INM) for sustaining crop productivity and reducing environmental impact: a review," Science of the Total Environment, vol. 512513, pp. 415-427, 2015.

[63] D. Bourn and J. Prescott, "A comparison of the nutritional value, sensory qualities, and food safety of organically and conventionally produced foods," Critical Reviews in Food Science and Nutrition, vol. 42, no. 1, pp. 1-34, 2002.

[64] H. Kuhnert, P. H. Feindt, S. Wragge, and V. Beusmann, "Nachfrage nach Öko-Lebensmitteln: ergebnisse einer repräsentativen Verbraucherstudie," in 7. Wissenschaftstagung zum Ökologischen Landbau, Ökologischer Landbau der Zukunft, Institute für Ökologischen, Vienna, Australia, 2003.

[65] A. B. Ghosh, "Soil fertility dynamics under different cropping systems," Fertilizer News, vol. 26, no. 9, pp. 64-70, 1980.

[66] K. Prasad and A. Rafey, "Effect of integrated weed management on weed growth, nutrientuptake, economics and energetics in rain-fed upland rice (Oryza sativa)," Indian Journal of Agricultural Science, vol. 65, pp. 260-264, 1995.

[67] P. V. V. Prasad, V. Satyanarayana, V. R. K. Murthy, and K. J. Boote, "Maximizing yields in rice-groundnut cropping sequence through integrated nutrient management," Field Crops Research, vol. 75, no. 1, pp. 9-21, 2002.

[68] V. Ramamurthy and K. Shivashankar, "Residual effect of organic matter and phosphorus on growth, yield and quality of maize," Indian Journal of Agronomy, vol. 41, no. 2, pp. 247-251, 1996.

[69] S. Goyal, K. Chander, M. C. Mundra, and K. K. Kapoor, "Influence of inorganic fertilizers and organic amendments on soil organic matter and soil microbial properties under tropical conditions," Biology and Fertility of Soils, vol. 29, no. 2, pp. 196-200, 1999.
[70] Z. Rengel, G. D. Batten, and D. E. Crowley, "Agronomic approaches for improving the micronutrient density in edible portions of field crops," Field Crops Research, vol. 60, no. 1-2, pp. 27-40, 1999.

[71] V. Kumar and I. P. S. Ahlawat, "Carry-over effect of biofertilizers and nitrogen applied to wheat (Triticum aestivum) and direct applied $\mathrm{N}$ in maize (Zea mays) in wheat maize cropping systems," Indian Journal of Agronomy, vol. 49, no. 4, pp. 233-236, 2004.

[72] S. M. Alam, S. A. Shah, S. Ali, and M. M. Iqbal, "Yield and phosphorus uptake by crops as influenced by chemical fertilizer and integrated use of industrial by-products," Songklanakarin Journal of Science and Technology, vol. 27, pp. 9-16, 2005.

[73] S. Zingore, R. J. Delve, J. Nyamangara, and K. E. Giller, "Multiple benefits of manure: the key to maintenance of soil fertility and restoration of depleted sandy soils on African smallholder farms," Nutrient Cycling in Agroecosystems, vol. 80, no. 3, pp. 267-282, 2008.

[74] R. Schulin, A. Khoshgoftarmanesh, M. Afyuni, B. Nowack, and E. Frossard, "Effect of soil management on zinc uptake and its bioavailability in plants," in Development and Uses of Biofortified Agricultural Products, G. S. Banuelos and Z. Lin, Eds., CRC Press, Boca Raton, FL, USA, 2009.

[75] P. A. Sánchez, "Tripling crop yields in tropical Africa," Nature Geoscience, vol. 3, no. 5, pp. 299-300, 2010.

[76] P. Marschner, D. Crowley, and Z. Rengel, "Rhizosphere interactions between microorganisms and plants govern iron and phosphorus acquisition along the root axis - model and research methods," Soil Biology and Biochemistry, vol. 43, no. 5, pp. 883-894, 2011.

[77] G. Ghosh and S. C. Poi, "Response of Rhizobium, phosphate soubilizing bacteria and mycorrhizal organism on some legume crops," Environmental Ecology, vol. 16, pp. 607-610, 1998.

[78] A. Bharali, K. K. Baruah, P. Bhattacharyya, and D. Gorh, "Integrated nutrient management in wheat grown in a northeast India soil: impacts on soil organic carbon fractions in relation to grain yield," Soil \& Tillage Research, vol. 168, pp. 81-91, 2017.

[79] A. K. I. Muhammad, H. Anwar, M. W. Razaza, and A. Muhammad, "Soil organic carbon, nitrate contents, physical properties and maize growth as influenced by dairy manure and nitrogen rates," International Journal of Agriculture and Biology, vol. 14, no. 1, pp. 20-28, 2012.

[80] M. H. Rahman, M. R. Islam, M. Jahiruddin, M. Y. Rafii, M. M. Hanafi, and M. A. Malek, "Integrated nutrient management in maize-legume-rice cropping pattern and its impact on soil fertility," Journal of Food, Agriculture \& Environment, vol. 11, no. 1, pp. 648-652, 2013.

[81] M. Chandrakala, C. A. Srinivasamurthy, S. Kumar, and D. V. Naveen, "Effect of application of graded level of phosphorus to finger millet-maize cropping system in soils of different P fertility," International Journal of Current Microbiology and Applied Sciences, vol. 6, no. 11, pp. 265-280, 2017.

[82] P. A. Barbieri, H. E. Echeverría, H. R. Saínz Rozas, and F. H. Andrade, "Nitrogen use efficiency in maize as affected by nitrogen availability and row spacing," Agronomy Journal, vol. 100, no. 4, pp. 1094-1100, 2008.

[83] L. Chuan, P. He, M. F. Pampolino et al., "Establishing a scientific basis for fertilizer recommendations for wheat in China: yield response and agronomic efficiency," Field Crops Research, vol. 140, pp. 1-8, 2013. 
[84] P. E. Fixen, F. Brentrup, T. BruuIsema, F. Garcia, R. Norton, and S. Zingore, Nutrient/Fertilizer Use Efficiency: Measurement, Current Situation and Trends, IFA, Rotterdam, Netherlands, 2014.

[85] S. Zingore, H. K. Murwira, R. J. Delve, and K. E. Giller, "Soil type, management history and current resource allocation: three dimensions regulating variability in crop productivity on African smallholder farms," Field Crops Research, vol. 101, no. 3, pp. 296-305, 2007.

[86] M. M. Hossain, M. N. A. Miah, M. A. Rahman, M. A. Islamand, and M. T. Islam, "Effect of salt stress on growth and yield attributes of mung bean," Bangladesh Research Publications Journal, vol. 1, no. 4, pp. 324-336, 2008.

[87] F. Zhang, Z. Cui, M. Fan, W. Zhang, X. Chen, and R. Jiang, "Integrated soil-crop system management: reducing environmental risk while increasing crop productivity and improving nutrient use efficiency in China," Journal of Environmental Quality, vol. 40, no. 4, pp. 1051-1057, 2011.

[88] H.-L. Zhang, R. Lal, X. Zhao, J.-F. Xue, and F. Chen, "Opportunities and challenges of soil carbon sequestration by conservation agriculture in China," Advances in Agronomy, vol. 124, pp. 1-36, 2014.

[89] R. N. Roy, A. Finck, G. J. Blair, and H. L. S. Tandon, Plant Nutrition for Food Security, FAO, Rome, Italy, 2006.

[90] A. Tirol-Padre, J. K. Ladha, A. P. Regmi, A. L. Bhandari, and K. Inubushi, "Organic amendments affect soil parameters in two long-term rice-wheat experiments," Soil Science Society of America Journal, vol. 71, no. 2, pp. 442-452, 2007.

[91] Y. Yu, L. Xue, and L. Yang, "Winter legumes in rice crop rotations reduces nitrogen loss, and improves rice yield and soil nitrogen supply," Agronomy for Sustainable Development, vol. 34, no. 3, pp. 633-640, 2014.

[92] R. Parkinson, P. Gibbs, S. Burchett, and T. Misselbrook, "Effect of turning regime and seasonal weather conditions on nitrogen and phosphorus losses during aerobic composting of cattle manure," Bioresource Technology, vol. 91, no. 2, pp. 171-178, 2004.

[93] R. Parkinson, "System based integrated nutrient management. By B. Gangwar \& V.K. Singh (eds). Published by new India publishing agency, New Delhi, India, (www.nipabooks.com) 2012. Xiii + 371 p. US\$90; INR2250. Hardback (ISBN 978-93-81450-05-5)," Soil Use and Management, vol. 29 , no. 4, p. $608,2013$.

[94] B. Kang and O. Osiname, "5. Micronutrient problems in tropical Africa," Fertilizer Research, vol. 7, no. 1-3, pp. 131-150, 1985.

[95] D. K. Roy, T. Chakraborty, G. Sounda, and S. Maitra, "Effect of fertility levels and plant population on yield and uptake of nitrogen, phosphorus and potassium in finger millet (Eleusine coracana) in lateritic soil of West Bengal," Indian Journal of Agronomy, vol. 46, pp. 707-711, 2001.

[96] P. Marschner, Mineral Nutrition of Higher Plants, Academic Press, Waltham, MA, USA, 3rd edition, 2012.

[97] B. K. Ramachandrappa, A. Sathish, G. N. Dhanapal, and P. N. S. Babu, "Nutrient management strategies for enhancing productivity of dryland crops in Alfisols," Indian Journal of Dryland Agricultural Research and Development, vol. 29, no. 2, pp. 49-55, 2014.

[98] J. S. Tenywa, P. Nyende, M. Kidoido, V. Kasenge, J. Oryokot, and S. Mbowa, "Prospects and constraints of finger millet production in Eastern Uganda," African Crop Science Journal, vol. 7, no. 4, pp. 569-583, 1999.
[99] P. Bhattacharyya, K. Chakrabarti, and A. Chakraborty, "Microbial biomass and enzyme activities in submerged rice soil amended with municipal solid waste compost and decomposed cow manure," Chemosphere, vol. 60, no. 3, pp. 310-318, 2005.

[100] P. Gruhn, F. Goletti, and M. Yudelman, Integrated Nutrient Management, Soil Fertility and Sustainable Agriculture: Current Issues and Future Challenges, International Food Policy Research Institute, Washington, DC, USA, 2000.

[101] K. G. Cassman, A. Dobermann, and D. T. Walters, "Agroecosystems, nitrogen-use efficiency, and nitrogen management," AMBIO: A Journal of the Human Environment, vol. 31, no. 2, pp. 132-140, 2002.

[102] J. A. Ogunwale, J. O. Olaniyan, and M. O. Adeloju, "Morphological, physiological and clay mineralogical properties of soil overlapping basement complex in Ilorin east, Nigeria," Moor Journal of Agricultural Research, vol. 3, no. 2, pp. 144-150, 2002.

[103] J. Ryan, R. Sommer, and H. Ibrikci, "Fertilizer best management practices: a perspective from the dryland West AsiaNorth Africa region," Journal of Agronomy and Crop Science, vol. 198, no. 1, pp. 57-67, 2012.

[104] M. Mgonja, P. Audi, A. P. Mgonja, E. Manyasa, and H. Ojulong, "Integrated blast and weed management and microdosing in finger millet," in A HOPE Project Manual for Increasing Finger Millet Productivity, International Crops Research Institute for the Semi-arid Tropics, Andhra Pradesh,India, 2013.

[105] CGIAR Annual Progress Report, CGIAR Research Program on Dryland Cereals, Performance Monitoring Re for Calendar Year 2013, CGIAR Annual Progress Report, Montpellier, France, 2013, http://www.cgiar.org/resources/crpdocuments/.

[106] S. Hemalatha and S. Chellamuthu, "Impacts of long term fertilization on soil nutritional quality under finger millet: maize cropping sequence," Journal of Environmental Research and Development, vol. 7, pp. 1571-1576, 2013.

[107] A. Akram, M. Fatima, S. Ali, G. Jilani, and R. Asghar, "Growth, yield and nutrients uptake of sorghum in response to integrated phosphorus and potassium management," Pakistan Journal of Botany, vol. 39, pp. 1083-1087, 2007.

[108] K. S. Chukwuka and O. E. Omotayo, "Effects of Tithonia green manure and water hyacinth compost application on nutrient depleted soil in South-Western Nigeria," International Journal of Soil Science, vol. 3, no. 2, pp. 69-74, 2008.

[109] D. J. Nath, B. Ozah, R. Baruah, R. C. Barooah, and D. K. Borah, "Effect of integrated nutrient management on soil enzymes, microbial biomass carbon and bacterial populations under rice (Oryza sativa)-wheat (Triticum aestivum) sequence," Indian Journal of Agricultural Science, vol. 81, pp. 1143-1148, 2011.

[110] T. K. Garai, J. K. Datta, and N. K. Mondal, "Evaluation of integrated nutrient management onbororice in alluvial soil and its impacts upon growth, yield attributes, yield and soil nutrient status," Archives of Agronomy and Soil Science, vol. 60, no. 1, pp. 1-14, 2014.

[111] S. Marimuthu, U. Surendran, and P. Subbian, "Productivity, nutrient uptake and post-harvest soil fertility as influenced by cotton-based cropping system with integrated nutrient management practices in semi-arid tropics," Archives of Agronomy and Soil Science, vol. 60, no. 1, pp. 87-101, 2014.

[112] V. Bairwa, R. Dahiya, P. Kumar, and V. K. Phogat, "Effect of long term integrated nutrient management on soil properties, soil fertility, nutrient uptake and crop yields under pearl 
millet-wheat cropping system," Research in Crops, vol. 14, no. 3, pp. 762-768, 2013.

[113] N. Brisson, P. Gate, D. Gouache, G. Charmet, F.-X. Oury, and F. Huard, "Why are wheat yields stagnating in Europe? A comprehensive data analysis for France," Field Crops Research, vol. 119, no. 1, pp. 201-212, 2010.

[114] S. Peng, J. Huang, X. Zhong et al., "Challenge and opportunity in improving fertilizer-nitrogen use efficiency of irrigated rice in China," Agricultural Sciences in China, vol. 1, pp. 776-785, 2002.

[115] N. D. Mueller, J. S. Gerber, M. Johnston, D. K. Ray, N. Ramankutty, and J. A. Foley, "Closing yield gaps through nutrient and water management," Nature, vol. 490, no. 7419, pp. 254-257, 2012.

[116] E. Davidson, J. Galloway, N. Millar, and A. Leach, "N-related greenhouse gases in north America: innovations for a sustainable future," Current Opinion in Environmental Sustainability, vol. 9-10, pp. 1-8, 2014.

[117] N. C. Brady and R. R. Weil, The Nature and Properties of Soil, MacMillan Publishing Co.Ltd., New York, NY, USA, 13th edition, 2005.

[118] D. Dawe, A. Dobermann, P. Moya et al., "How widespread are yield declines in long-term rice experiments in Asia?" Field Crops Research, vol. 66, no. 2, pp. 175-193, 2000.

[119] D. Dawe, A. Dobermann, J. K. Ladha et al., "Do organic amendments improve yield trends and profitability in intensive rice systems?" Field Crops Research, vol. 83, no. 2, pp. 191-213, 2003.

[120] M. M. Wahba, "Influence of compost on morphological and chemical properties of sandy soils, Egypt," Journal of Applied Sciences Research, vol. 3, pp. 1490-1493, 2007.

[121] F. Bastida, E. Kandeler, T. Hernández, and C. García, "Longterm effect of municipal solid waste amendment on microbial abundance and humus-associated enzyme activities under semiarid conditions," Microbial Ecology, vol. 55, no. 4, pp. 651-661, 2008.

[122] D. S. Rathore, H. S. Purohit, L. Yadav, and S. R. Sharma, "Effect of integrated nutrient management on soil properties and crop yield under black gram-wheat cropping system in a typic haplustept," Annals of Arid Zone, vol. 50, no. 1, pp. 21-26, 2011.

[123] M. R. Davari, S. N. Sharma, and M. Mirzakhani, "The effect of combinations of organic materials on productivity, grain quality, nutrient uptake and economics in organic farming wheat," Journal of Organic Systems, vol. 7, no. 2, pp. 26-35, 2012.

[124] L. Aula, N. Macnack, P. Omara, J. Mullock, and W. Raun, "Effect of fertilizer nitrogen (N) on soil organic carbon, total $\mathrm{N}$, and soil $\mathrm{pH}$ in long-term continuous winter wheat (Triticum aestivum L.)," Communications in Soil Science and Plant Analysis, vol. 47, no. 7, pp. 863-874, 2016.

[125] R. Kumari, S. Kumar, R. Kumar et al., "Effect of long-term integrated nutrient management on crop yield, nutrition and soil fertility under rice-wheat system," Journal of Applied and Natural Science, vol. 9, no. 3, pp. 1801-1807, 2017.

[126] L. Van-Camp, Reports of the Technical Working Groups Established under the Thematic Strategy for Soil Protection EUR21319 EN/3, Office for Official Publications of the European Communities, Luxembourg, 2004.

[127] Y. Zhao, P. Wang, J. Li, Y. Chen, X. Ying, and S. Liu, "The effects of two organic manures on soil properties and crop yields on a temperate calcareous soil under a wheat-maize cropping system Mogotsi," in PROTA 1: Cereals andpulses/
Céréalesetlégumessecs, M. Brink and G. Belay, Eds., PROTA, Wageningen, Netherlands, 2009.

[128] W. Mohammad, S. M. Shah, S. Shehzadi, and S. A. Shah, "Effect of tillage, rotation and crop residues on wheat crop productivity, fertilizer nitrogen and water use efficiency and soil organic carbon status in dry area (rainfed) of north-west Pakistan," Journal of Soil Science and Plant Nutrition, vol. 12, no. 4, pp. 715-727, 2012.

[129] D. Lobo, D. Gabriels, and G. Depaola, Effect of Soil Conditioners on Nutrient Uptake by a Green Pepper Crop, International centre for hemorology, Ghent University, Belgium, China, 2012.

[130] S. L. Postel, "Entering an era of water scarcity: the challenges ahead," Ecological Applications, vol. 10, no. 4, pp. 941-948, 2000.

[131] I. Sönmez, M. Kaplan, and S. Sönmez, "Effect of chemical fertilizers on environmental pollution and its prevention methods," Batı Akdeniz Tarımsal Araştırma Enstitüsü Derim Dergisi, vol. 25, pp. 24-34, 2008.

[132] E. Truog, "Soil reaction influence on availability of plant nutrients," Soil Science Society of America, vol. 11, pp. 305308, 1946.

[133] N. G. Boschetti, C. E. Quintero, and L. Giuffre, "Phosphorus fractions of soils under Lotus corniculatus as affected by different phosphorus fertilizers," Biology and Fertility of Soils, vol. 45, no. 4, pp. 379-384, 2009.

[134] M. Kaya, K. Zeliha, and I. Erdal, "Effects of elemental sulfur and sulfur containing waste on nutrient concentrations and growth of bean and corn plants grown on a calcareous soil," African Journal of Biotechnology, vol. 8, no. 18, pp. 44814489, 2009.

[135] H. Li, J. Shen, F. Zhang, Z. Marschner, G. Cawthray, and Z. Rengel, "Phosphorus uptake and rhizosphere properties of intercropped and monocropped maize, faba bean, and white lupin in acidic soil," Biology and Fertility of Soils, vol. 46, no. 2, pp. 79-91, 2010

[136] M. Motior Rahman, A. S. Abdou, H. A. D. F. G. Fareed, and M. Sofian Azirun, "Growth and nutrient uptake of maize plants as affected by elemental sulfur and nitrogen fertilizer in sandy calcareous soil," African Journal of Biotechnology, vol. 10, no. 60, pp. 12882-12889, 2011.

[137] A. O. Esilaba, J. B. Byalebeka, R. J. Delve et al., "On farm testing of integrated nutrient management strategies in eastern Uganda," Agricultural Systems, vol. 86, no. 2, pp. 144-165, 2004.

[138] A. K. Sarkar, "Long term effects of fertilizer, organic manure \& journal of biology," Agriculture and Healthcare, vol. 5, no. 13, 2007.

[139] X. Yang, W. Ren, B. Sun, and S. Zhang, "Effects of contrasting soil management regimes on total and labile soil organic carbon fractions in a loess soil in China," Geoderma, vol. 177-178, pp. 49-56, 2012.

[140] U. K. Behera, A. R. Sharma, and H. N. Pandey, "Sustaining productivity of wheat-soybean cropping system through integrated nutrient management practices on the Vertisols of central India," Plant and Soil, vol. 297, no. 1-2, pp. 185-199, 2007.

[141] M. S. Mavi and D. K. Benbi, "Potassiumdynamics under integrated nutrient management in rice-wheat system," Agrochimica, vol. 52, pp. 83-91, 2008.

[142] W. Mohammad, Z. Shah, S. M. Shah, and S. Shehzadi, "Response of irrigated and N-fertilized wheat to legumecereal and cereal-cereal rotation," Soil Environment, vol. 27, no. 2, pp. 148-154, 2008. 
[143] S. Samreen, S. Zahir, and M. Wisal, "Residual effect of organic wastes and chemical fertilizers on wheat yield under wheat-maize cropping sequence," Soil Environment, vol. 33, no. 2, pp. 88-95, 2014.

[144] N. Bolan, D. Adriano, and S. Mahimairaja, "Distribution and bioavailability of trace elements in livestock and poultry manure by-products," Critical Reviews in Environmental Science and Technology, vol. 34, no. 3, pp. 291-338, 2004.

[145] N. S. Bolan, G. Choppala, A. Kunhikrishnan, J. Park, and R. Naidu, "Microbial transformation of trace elements in soils in relation to bioavailability and remediation," Reviews of Environmental Contamination and Toxicology, vol. 225, pp. 1-56, 2013.

[146] R. Sushila and G. I. R. I. Gajendra, "Influence of farmyard manure, nitrogen and biofertilizers on growth yield attributes and yields of wheat under limited water supply," Indian Journal of Agronomy, vol. 45, pp. 590-595, 2000.

[147] G. L. Wells, R. S. Malpass, R. C. L. Lindsay, R. P. Fisher, J. W. Turtle, and S. M. Fulero, "From the lab to the police station: a successful application of eyewitness research," American Psychologist, vol. 55, no. 6, pp. 581-598, 2000.

[148] K. M. Camara, W. A. Payne, and P. E. Rasmussen, "Longterm effects of tillage, nitrogen, and rainfall on winter wheat yields in the pacific northwest," Agronomy Journal, vol. 95, no. 4, pp. 828-835, 2003.

[149] W. Mohammad, Z. Shah, S. M. Shah, and M. M. Iqbal, "Wheat yield, fertilizer $\mathrm{N}$ utilization and water use efficiency as influenced by tillage and $\mathrm{P}$ levels under rainfed conditions," Pakistan Journal of Soil Science, vol. 22, no. 1, pp. 11-18, 2003.

[150] N. S. Bolan, D. C. Adriano, and D. Curtin, "Soil acidification and liming interactions with nutrientand heavy metal transformationand bioavailability," Advances in Agronomy, vol. 78, pp. 215-272, 2003.

[151] K. M. Hati, K. G. Mandal, A. K. Misra, P. K. Ghosh, and K. K. Bandyopadhyay, "Effect of inorganic fertilizer and farmyard manure on soil physical properties, root distribution, and water-use efficiency of soybean in vertisols of central India," Bioresource Technology, vol. 97, no. 16, pp. 2182-2188, 2006.

[152] L. M. Carrera, J. S. Buyer, B. Vinyard, A. A. Abdul-Baki, L. J. Sikora, and J. R. Teasdale, "Effects of cover crops, compost, and manure amendments on soil microbial community structure in tomato," Applied Soil Ecology, vol. 37, no. 3, pp. 247-255, 2007.

[153] T. Deksissa, I. Short, and J. Allen, "Effect of soil amendment with compost on growth and water use efficiency of Amaranth," in Proceedings of the UCOWR/NIWR Annual Conference, International Water Research Challenges for the 21st Century and Water Resources Education, Durham, NC, USA, July 2008.

[154] M. Odlare, M. Pell, and K. Svensson, "Changes in soil chemical and microbiological properties during 4 years of application of various organic residues," Waste Management, vol. 28, no. 7, pp. 1246-1253, 2008.

[155] S. Peng, R. J. Buresh, J. Huang et al., "Improving nitrogen fertilization in rice by sitespecific N management. A review," Agronomy for Sustainable Development, vol. 30, no. 3, pp. 649-656, 2010.

[156] D. K. Parmer and V. Sharma, "Studies on long term application of fertilizers and manure on yield of maize-wheat rotation and soil properties under rainfed conditions in western Himalayas," Journal of the Indian Society of Soil Science, vol. 50, no. 3, pp. 311-312, 2002.
[157] W. Cheuk, K. V. Lo, R. M. R. Branion, and B. Fraser, "Benefits of sustainable waste management in the vegetable greenhouse industry," Journal of Environmental Science and Health, Part B, vol. 38, no. 6, pp. 855-863, 2003.

[158] G. Sarwar, N. Hussain, H. Schmeisky, and S. Muhammad, "Use of compost an environment friendly technology for enhancing rice-wheat production in Pakistan," Pakistan Journal of Botany, vol. 39, no. 5, pp. 1553-1558, 2007.

[159] G. Sarwar, N. Hussain, H. Schmeisky, S. Muhammad, M. Ibrahim, and E. Safdar, "Improvement of soil physical and chemical properties with compost application in ricewheat cropping system," Pakistan Journal of Botany, vol. 40, no. 1 , pp. 275-282, 2008.

[160] T. Abedi, A. Alemzadeh, and S. A. Kazemeini, "Effect of organic and inorganic fertilizers on grain yield and protein building pattern of wheat," Australian Journal of Crop Science, vol. 4, no. 6, pp. 384-389, 2010.

[161] S. Ghosh, "Management of soil quality and carbon sequestration with long-term application of organic amendments," in Proceedings of 19th World Congress of Soil Science, Soil Solutions for a Changing World, pp. 146-149, Brisbane, Australia, August, 2010.

[162] M. Diacono and F. Montemurro, "Long-term effects of organic amendments on soil fertility. A review," Agronomy for Sustainable Development, vol. 30, no. 2, pp. 401-422, 2010. 